\title{
A Study on Employee Voice and its Effect on Work Engagement: Explicating from the Turkish Teachers' Perspectives
}

\author{
Yücel Şimşek ${ }^{1} \&$ Muhammed Gürler ${ }^{2}$ \\ ${ }^{1}$ Faculty of Education, Anadolu University, Eskişehir, Turkey \\ ${ }^{2}$ Republic of Turkey Ministry of National Education, Ankara, Turkey \\ Correspondence: Muhammed Gürler, Republic of Turkey Ministry of National Education, Ankara, Turkey. \\ E-mail: muhammedgurler@hotmail.com
}

\author{
Received: February 2, $2019 \quad$ Accepted: March 18, $2019 \quad$ Online Published: June 29, 2019 \\ doi:10.5539/ies.v12n7p80 URL: https://doi.org/10.5539/ies.v12n7p80
}

\begin{abstract}
The objective of the present study is to investigate the effect of employee voice on work engagement according to the views of the Turkish teachers. The sample of the study consisted of 713 teachers randomly selected at 40 public schools from kindergarten to high school from Ayaş, Beypazarı, Güdül and Sincan districts of Ankara, the capital city of Turkey. In order to collect the data for this study, Employee Voice and Work Engagement scales were used. All scales were adapted to the school environment by translation and back translation method. The construct validity and reliability of the scales were examined through Exploratory Factor Analysis, Confirmatory Factor Analysis and Cronbach Alfa, Composite Reliability, Average Variance Explained values. In the first step of the data analysis process; arithmetic means, standard deviations, skewness and kurtosis values were calculated. Relations between the variables were measured by the Pearson product-moment correlation coefficient and regression analysis. Consequently, the results of study show that there is a positive and significant relationship between employee voice and work engagement. Besides, employee voice is a significant predictor for work engagement. The findings of the study exhibit that the level of teachers' employee voice and work engagement are high degree.
\end{abstract}

Keywords: employee voice, work engagement, teachers, school

\section{Introduction}

In today's rapidly growing and evolving world, challenging and overcoming the work issues and difficulties without employees' help easily by top managers in the organizations seem to be a thing of the past. That is why it remains as a memory from the old days that the executives decide and employees perform (Senge, 1990). Nowadays human capital has converted a crucial strategic and intellectual asset for organizations (Han, Chiang \& Chang, 2010). As Drucker (1999) asserted: "The most valuable assets of a 20th-century company was its production equipment. The most valuable asset of a 21 st-century institution (whether business or nonbusiness) will be its knowledge workers and their productivity."

Organizations need employees' opinions, voice, for making better processes, products and services in order to maintain competitive advantage (Botero \& Van Dyne, 2009). On the other side, employees deserve to take part in organizational decision making by using their ideas, because it provides a sense of belonging and psychological ownership to their organizations. As a result of employee participation in decision making, employees gladly devote more time and take more responsibilities at work, developing organizational commitment, efficiency and knowledge-sharing (Han, Chiang, \& Chang, 2010). Thus, employees who have autonomy, control and responsibility in their organizations will be more engaged to their work (Bakker \& Demerouti, 2008). When we look at employee voice from the teachers' perspective, teachers don't have an adequate voice in setting educational policy and decision-making in spite of their considerable responsibilities (Gyurko, 2012). Hargreaves (1996) defined teacher voice as a role that teachers play in school restructuring and reform. Heneveld (2007) said that teachers are the most powerful persons to affect the changes directed to the educational decisions. However, nobody attaches great importance to the teachers during the decision making stage. Because, teachers have inadequate power or control over critical decisions that influence their work (Ingersoll, 2003). Although teachers are at the heart of the educational improvement and change (Hopkins \& Stern, 1996; Al Bataineh \& Awaleh, 2005). Hargreaves and Shirley (2011) emphasized that teachers are mostly the very last persons who hear, learn and speak 
about educational reforms. According to the research about teachers' voice that was applied in the United States, $69 \%$ of the teachers' population lacked sufficient voice on the discussions about school and education issues (Markow \& Pieters, 2010). For this reason, to improve the teacher quality at schools, more control needs to be given to the teachers in shaping students' growth and learning (Ingersoll, 2003).

This study aims to reveal the relationship between employee voice and work engagement. Because, Saks and Gruman (2014) explained that employee voice and work engagement is parallel to each other at many points. So, this relationship should be investigated carefully through different conceptual and empirical works. Reissner and Pagan (2013) also underlined that it is necessary to examine the relationship between communication and engagement in the organizations. On the other hand, Cheng, Lu, Chang, and Johnstone (2013) indicated that most voice behavior researchers have concentrated mostly on discovering the antecedents of voice behavior, but little is known about consequences of voice behavior. Work engagement might be considered as one of the consequences of employee voice. For that reason, employee voice and work engagement will be discussed and investigated as a probable consequence of voice behavior in this research through the views of the teachers at schools in Turkey. Because, teacher engagement is vital not only for teachers, but also for students, parents, schools and the educational system in general (Burić \& Macuka, 2017).

In the following, a review of literature on employee voice and work engagement will be explained first, then the aim of the study and methods will be presented. Next, the results of the analysis and discussions of the findings will be summarized briefly. Finally, implications or suggestions for practice, theory and future studies will be outlined at the end.

\section{Theoretical Background}

\subsection{Employee Voice}

The idea of Employee voice has been the center of the spotlights in the fields of Employment Relations/Human Resource Management (ER/HRM) and Organizational Behavior (OB) since the 1980s (Wilkinson, Gollan, Kalfa, $\& \mathrm{Xu}, 2018)$. However, Hirschman's (1970) influential book "Exit, Voice, and Loyalty" is accepted as a milestone for employee voice. On the other hand, Kaufman (2013) claimed that the concept of employee voice traces its roots back to the Industrial Revolution. According to Kaufman (2013), the concept of employee voice came to existence with the publication of Adam Smith's masterpiece of economic analysis "Wealth of Nations (1776/1937)". In his book, Smith explicitly argues the notion of employee voice. He indicates that, "The laborer['s]... voice is little heard and less regarded [except] upon some particular occasion, when his clamour is animated" (Kaufman, 2013, pp. 396-397).

In this day and age, so many usages and definitions have been addressing to employee voice from various fields and perspectives such as Hirschman's model, Employment Relations/Human Resource Management, Organizational Behavior and Organizational Justice literatures, which can sometimes lead to confusion to get the point of employee voice (Wilkinson et al., 2018; Morrison, 2011). Employee voice explanations from different fields will be explained respectively below.

Firstly, Hirschman's (1970) “Exit, Voice, Loyalty” and later “Neglect” (EVLN) (Rusbult, Zembrodt \& Gun, 1982) was added this model defined voice as a reaction of employees or customers due to the deterioration or dissatisfaction towards to their firms, performance or products. As a result of this deterioration, employees or customers struggle to make better the circumstances by choosing one of the options from EVLN model. First option from the model is exit. Exit means that moving away the organization as an employee or no more buying the products of the firms as a customer. Second option is voice. Voice means that sharing the opinions about the work issues, projects or procedures at work to the managers, colleagues or others, who stand outside of their organizations such as unions, agencies, authorized people from the government and so on to get help about the issues and improve the working conditions. In other words, voice comes to exist as a response to unsatisfied or worsening conditions in the organizations. Third option is loyalty. Loyalty is being patient and expecting that deterioration and dissatisfaction will disappear in a short time. Employees or customers set time aside for their organizations for better results. The last choice is neglect. It means that ignoring the facts and issues that disturb you at work and behaving recklessly or tending to engage in deception (Hirschman, 1970). Farrell and Rusbult (1992) implied that voice is active and constructive, but, to the contrary, neglect is passive and destructive.

Secondly, "Employment Relations/Human Resource Management" literature described voice as a wide range of formal mechanisms for individual and collective employee input, such as grievance procedures, suggestion systems, ombudsman services, employee-management meetings, non-management task forces, quality circles, work councils, and participative management (Morrison, 2011). ER/HRM considers employee voice as a basic democratic act for employees to have a right to comment on decision making at work in their organizations 
(Wilkinson et al., 2018).

Thirdly, "Organizational Justice" literature defined employee voice as having chances to express their opinions in a fair way than watching silently by joining decision making procedures, performance evaluations and compensation plans and conflict management in the organizations. Moreover, if employees believe that the decisions are taken fairly, they will be more supportive even when the decisions are negative or disapproving for themselves (Bies \& Shapiro, 1988).

Finally, "Organizational Behavior" literature identified voice as a reaction to dissatisfaction circumstances in the organizations, as an extra role behavior or non-compulsory work. Employees, who have voice behavior, perform above and beyond the call of their duties at work of their own free will. Employees share their ideas, suggestions, information or apprehensions in an informal, innovative and intentional way about new projects, procedures, unfairness, misconduct or work issues to the persons who can make proper and necessary moves for the purpose of improving the conditions or functions by doing constructive changes or developments to recover and alter the existing status quo, even if the others don't agree with them in the organizations (Morrison, 2011; 2014). Premaux and Bedeian (2003) also described voice as speaking up of the employees about work related issues.

As a conclusion, employee voice may elicit many valuable improvements for the organizations such as enhanced organizational decision making, discovering the real reasons of the problems about work issues (Morrison \& Milliken, 2000), organizational commitment (Farndale, Van Ruiten, Kelliher, \& Hope-Hailey, 2011), increasing organizational learning (Argyris \& Schon, 1978); organizational innovation (Nemeth, 1985), job satisfaction (Holland, Cooper, \& Sheehan, 2011; Wood \& De Menezes, 2011), low intention to quit (Spencer, 1986) and employee engagement (Rees, Alfes, \& Gatenby, 2013; Ruck, Welch, \& Menara, 2017; Purcell, 2014).

\subsection{Work Engagement}

The positive psychology movement appeared as a response to trends in psychology about negative and disease sides of human behaviors and characteristics and focused on the positive sides and strengths of human behaviors and characteristics. Considering the reflection of this point of view in the organizational behavior, positive organizational behavior emerged. This movement is described as "the study and application of positively oriented human resource strengths and psychological capacities that can be measured, developed, and effectively managed for performance improvement in today's workplace" (Luthans, 2002).

Work engagement, a positive, fulfilling, work-related state of mind, is one of the constructs of positive organizational behavior (Bakker \& Demerouti, 2008) and today's organizations require engaged employees (Bakker \& Schaufeli, 2008). Work engagement is described as having a positive and satisfying mood at work that is depicted by vigor, dedication, and absorption. It is not a temporary and specific mood; it is more insistent and all pervasive affective and cognitive mood (Schaufeli, Salanova, Gonzàlez-Romà, \& Bakker, 2002). Vigor is depicted as being very energetic, enthusiastic, diligent and having mental resilience while working even in the presence of difficulties. Dedication is being intensely engaged in one's work and experiencing a sense of significance, enthusiasm and challenge. Absorption is described as being entirely focused and absorbed with joy in one's work so that time flies. Moreover, it is really hard to remove oneself from work (Bakker \& Demerouti, 2008).

Work engagement is a key determinant of individual and organizational performance outcomes. Moreover, it is profitable not only for employees but also for organizations, because engaged employees display superior job performance in their organizations (Demerouti \& Cropanzano, 2010). Besides, employee engagement is an outstanding instrument for the organizations to increase their own competitive advantage over others (Latif \& Arif, 2018). Furthermore, it was found that engaged employees perform well and are enthusiastic to go the extra mile at work (Bakker, Albrecht, \& Leiter, 2011). Engaged employees perform better performance in their organizations and show positive emotions towards their work such as happiness, joy, and enthusiasm contrary to non-engaged workers (Bakker \& Demerouti, 2008) and organizations can take advantage of engagement-evoking working environments by encouraging work engagement among their employees (Liang, Yehuda, \& Russo, 2017). A research of 50,000 participants joined that the most engaged and committed employees fulfill their work 20 per cent better than their colleagues (Corporate Leadership Council, 2004).

\section{Method}

\subsection{Research Design}

In this research, relational screening model was used to investigate the effects of employee voice on work engagement. The relational screening model is appropriate for the studies that intends for describing a situation in the past or present as it is. Besides, it is suitable for showing the covariances between the two or more variables (Karasar, 2006). 


\subsection{Research Sample}

The sample of the investigation consisted of 713 teachers employed at 40 public schools (kindergarten, primary, secondary, high schools) from Ayaş, Beypazarı, Güdül and Sincan districts of Ankara, Turkey.

Some demographic features of the participants can be seen in Table 1:

Table 1. Demographic features of the teachers

\begin{tabular}{|c|c|c|c|}
\hline \multicolumn{2}{|c|}{ Demographic Variables } & \multirow{2}{*}{$\frac{\mathrm{n}}{198}$} & \multirow{2}{*}{$\frac{\%}{27.8}$} \\
\hline & Female & & \\
\hline Gender & Male & 515 & 72.2 \\
\hline \multirow{5}{*}{ Tenure } & 1. $1-5$ years & 131 & 18.4 \\
\hline & 2. $6-10$ years & 162 & 22.7 \\
\hline & 3. $11-15$ years & 123 & 17.3 \\
\hline & 4. 16-20 years & 157 & 22.0 \\
\hline & 5. 21 years and over & 140 & 19.6 \\
\hline
\end{tabular}

As shown in Table 1, 198 (27.8\%) of the teachers in the sample are female and $515(72.2 \%)$ are male. Therefore, nearly one fourth of the sample is female in this research. A review of the Table 1 also provides some information about the teachers' tenure as a teacher. 131 of the teachers (18.4\%) have between one and five, 162 of the teachers $(22.7 \%)$ have between six and ten years, 123 of the teachers (17.3\%) have between eleven and fifteen years, 157 of the teachers $(22.0 \%)$ have between sixteen and twenty years, 140 of the teachers $(19.6 \%)$ have between twenty-one years and over tenure as a teacher. Teachers who have 1 and 5 years' tenure $(18.4 \%)$ have the lowest percentage but teachers who have between six and ten years' tenure (22.7\%) has the highest percentage.

\subsection{Research Instruments}

To collect the data for this research, two different measurement instruments were used. These scales are Employee Voice Scale and Work Engagement Scale.

\subsubsection{Employee Voice Scale}

This scale developed by Van Dyne and LePine (1998), translated into Turkish and made suitable for teachers and school environment by Gürler (2018). It contains 7 items in the form of 5-point Likert-type scale, which graded between 1 (I completely disagree) and 5 (I completely agree). Though, it was at first designed as 7-point Likert-type with 6 items. In this current research, the sixth item of the authentic scale separated into two distinct items to be understood without difficulty in Turkish environment.

The Kaiser-Meyer-Olkin (KMO) Measure of Sampling Adequacy (MSA) test and Bartlett's test of sphericity were applied to investigate the suitability of factor analysis. KMO was measured as .84 above critical value .50 (Tabachnick \& Fidell 2007) and Barlett's Sphericity Test was statistically significant $\chi^{2}=(21)=1971.946, p<.001$. Thus, the quantity of the sample is "perfectly" sufficient for factor analysis (Hutcheson \& Sofroniou, 1999). Consistent with the findings, a single factor structure with an eigenvalue $\lambda=3.720$ was extracted from the employee voice scale.

The internal consistency reliability of the scale was evaluated by measuring Cronbach's alpha and Composite Reliability (CR). The Cronbach's Alpha value of the Turkish adapted scale is .85 and composite reliability is .87 . Both values are above the threshold level .70 (Nunnally \& Bernstein, 1994). Consequently, the scale can be assessed as a reliable tool to measure the employee voice. Additionally, corrected items total correlation coefficients ranked between .56 and .71. Factor load values of the items changed between .69 and .81 and besides the total variance with a single factor explained is around $53 \%$. Explained variance value should be at least $30 \%$ for scales with a single factor (Büyüköztürk, 2003). For that reason, this value can be appraised as suitable and sufficient for doing analysis.

To confirm the construct validity, convergent and discriminant validity were measured. Average Variance Extracted (AVE) and factor loadings must be over .50 for convergent validity (Fornel \& Larcker, 1981; Peterson, 2000). Calculated AVE is .44 and factor loading is .53. It is found that AVE of the scale is lower than the threshold level .50. In the face of such a situation, Fornel and Larcker (1981) remarked to the CR value of the scale to learn whether it has convergent validity or not. They claimed that the scale will have convergent validity, if the CR value is .60 or over. In this regard, CR of the employee voice scale is .87 . and it is obvious that the scale has convergent validity. The scale has discriminant validity, too. Because, the square root of AVE is .66 and this finding is higher 
than the correlation value $(\mathrm{r}=.50)$.

Whether the construct that acquired from exploratory factor analysis (EFA) is appropriate or not with the research data, the confirmatory factor analysis (CFA) was applied. CFA was implemented by using AMOS 24 software program. Table 2 shows that the necessary and good levels of fit indices of the employee voice scale, which were attained by confirmatory factor analysis.

Table 2. Goodness-of-Fit indices for employee voice

\begin{tabular}{cc}
\hline The Fit Indices & Acceptable Fit \\
\hline $\mathrm{X}^{2} / \mathrm{sd}=4.099$ & $<5$ \\
$\mathrm{GFI}=.985$ & $>.90$ \\
$\mathrm{AGFI}=.957$ & $>.90$ \\
$\mathrm{CFI}=.984$ & $>.90$ \\
$\mathrm{NFI}=.979$ & $>.90$ \\
$\mathrm{RMSEA}=.066$ & $<.08$ \\
$\mathrm{RMR}=.022$ & $<.08$ \\
$\mathrm{SRMR}=.0275$ & $<.05$ \\
\hline
\end{tabular}

After applying the confirmatory factor analysis, $t$ values of the items were examined. If the $t$ value is over 1.96 , $(\mathrm{p}<.05)$ or 2.58, ( $\mathrm{p}<.01)$, It is statistically significant (Jöreskog \& Sörbom, 1993; Kline, 2011). t values, which aren't significant must be omitted from the model or the number of the participants in the research aren't sufficient and should be enlarged (Byrne, 2010).

In Table 3, standardized regression coefficients, standard errors, $t$ and $\mathrm{R}^{2}$ values are presented by using path analysis to the employee voice.

Table 3. Results of confirmatory factor analysis for employee voice

\begin{tabular}{cccccc}
\hline Path from Employee Voice to & Standardized Regression Coefficients & Standard Error & $\mathrm{t}$ value & $\mathrm{p}$ & $\mathrm{R}^{2}$ \\
\hline Emp. Voice1 & .75 & & & & .57 \\
Emp. Voice2 & .59 & .05 & 14.0 & $*$ & .35 \\
Emp. Voice3 & .52 & .04 & 12.3 & $*$ & .27 \\
Emp. Voice4 & .60 & .04 & 14.1 & $*$ & .36 \\
Emp. Voice5 & .73 & .05 & 14.9 & $*$ & .55 \\
Emp. Voice6 & .73 & .06 & 16.1 & $*$ & .53 \\
Emp. Voice7 & .67 & .06 & 15.1 & $*$ & .45 \\
\hline
\end{tabular}

$* \mathrm{p}<.001$

As showed in Table 3, all $t$ values are over $1.96(t>1.96)$ and statistically significant $(\mathrm{p}<0.001)$. It means that the number of the participants in the study is acceptable and it isn't necessary to omit any items from the employee voice scale. Moreover, the first item of the employee voice is the most explanatory item in the scale in line with the data derived from regression analysis results $\left(\mathrm{R}^{2}=.57\right)$.

\subsubsection{Work Engagement Scale}

Utrecht Work Engagement Scale (UWES-9) short form was applied to measure the work engagement level of the teachers. This scale developed by Schaufeli and Bakker (2004), translated into Turkish and adapted to the teachers and school context by Gürler (2018). Originally, this scale has got 17 items and three dimensions, namely "vigor, dedication and absorption". However, Schaufeli, Bakker and Salanova (2006) asserted that UWES-9 can be used as an overall measure of work engagement. They also claimed that the researchers might use the total nine-item score as an indicator of work engagement instead of calculating three different scores for vigor, dedication and absorption. Therefore, it can be used as whether as a single factor or three factors measurement tool (Schaufeli, Bakker \& Salanova, 2006). Sonnentag (2003) stated that measuring work engagement through single factor with a total score will cause better and accurate results. UWES-9 scale involves 9 items. In this present study, it was used in the form of 5-point Likert-type scale, which ranked between 1 (never) and 5 (always) to be understood without difficulty in Turkish environment. However, it was originally designed as 7-point Likert-type.

KMO was found to be .89 and Barlett's Sphericity Test was statistically significant $\chi^{2}=(36)=2725.272, p<.001$. According to the findings, a single factor structure with an eigenvalue $\lambda=4.634$ was extracted from the UWES-9 
scale.

The Cronbach's Alpha value of the Turkish adapted scale is .88 and composite reliability is .93 . Corrected items total correlation coefficients ranged between .54 and .69. Factor load values of the items varied between .64 and .78 as well as the total variance with a single factor explained is around $51 \%$. Explained variance value should be at least $30 \%$ for scales with a single factor (Büyüköztürk, 2003). Therefore, this value can be evaluated as satisfactory and sufficient for doing analysis.

Calculated AVE is .44 and factor loading is .51. It is observed that AVE of the scale is lower than the threshold level .50. In this case, Fornel and Larcker (1981) remarked to the CR value of the scale to decide whether the scale has convergent validity or not. They implied that the scale will have convergent validity, if the CR value is .60 or over. In this sense, CR of the employee voice scale is .87. And it is obvious that the scale has convergent validity. The scale has also discriminant validity. Because, the square root of AVE is .67 and higher than the correlation value $(\mathrm{r}=.50)$.

In Table 4 fit indices of the UWES-9 scale were presented and the results showed that good and adequate levels of fit indices of the scale.

Table 4. Goodness-of-Fit indices for work engagement

\begin{tabular}{cc}
\hline The Fit Indices & Acceptable Fit \\
\hline $\mathrm{X}^{2} / \mathrm{sd}=4.481$ & $<5$ \\
$\mathrm{GFI}=.971$ & $>.90$ \\
$\mathrm{AGFI}=.940$ & $>.90$ \\
$\mathrm{CFI}=.972$ & $>.90$ \\
$\mathrm{NFI}=.964$ & $>.90$ \\
$\mathrm{RMSEA}=.070$ & $<.08$ \\
$\mathrm{RMR}=.015$ & $<.08$ \\
$\mathrm{SRMR}=.0303$ & $<.05$ \\
\hline
\end{tabular}

In Table 5, standardized regression coefficients, standard errors, $t$ and $\mathrm{R}^{2}$ values are displayed. According to the findings, all $t$ values are over $1.96(t>1.96)$ and statistically significant $(\mathrm{p}<0.001)$. On the other hand, the third item of the work engagement scale is the most explanatory item in the scale $\left(\mathrm{R}^{2}=.58\right)$.

Table 5. Results of confirmatory factor analysis for work engagement

\begin{tabular}{cccccc}
\hline Path from Work Enagagement to & Standardized Regression Coefficients & Standard Error & $\mathrm{t}$ value & $\mathrm{p}$ & $\mathrm{R}^{2}$ \\
\hline W.E. 1 & .67 & & & & \\
W.E. 2 & .74 & .06 & 19.7 & $*$ & .55 \\
W.E. 3 & .76 & .07 & 17.1 & $*$ & .58 \\
W.E. 4 & .70 & .08 & 15.8 & $*$ & .48 \\
W.E. 5 & .65 & .09 & 14.8 & $*$ & .42 \\
W.E. 6 & .72 & .08 & 16.3 & $*$ & .52 \\
W.E. 7 & .57 & .07 & 13.3 & $*$ & .32 \\
W.E. 8 & .55 & .07 & 13.0 & .30 \\
W.E. 9 & .60 & .07 & 14.0 & .36 \\
\hline
\end{tabular}

$* \mathrm{p}<0.001$.

\subsection{Data Analysis}

Data analysis was applied in two phases. Firstly, the research data are organized to investigate and secondly the analyses towards the research were performed through SPSS 24 software program.

Firstly, to control the dataset is acceptable for normal distribution "skewness and kurtosis" values were measured. Because normal distribution is required for applying statistical tests towards the dataset. When the data isn't normally distributed, the results of the statistical tests can be specious and deficient (Kalayc1, 2006). Next, descriptive statistics (minimum, maximum values, mean, standard deviation, skewness, kurtosis, frequency distribution, and percentage values) were implemented to calculate the levels of the teachers' employee voice and 
work engagement. Then, the Pearson product-moment correlation coefficient (PPMCC) was found if the relationship between two variables are statistically significant or not. Finally, regression analysis was performed for presenting if employee voice predicts work engagement significantly.

\section{Findings}

First, this research targeted to discover the Turkish Teachers' employee voice level and its Effect on Work Engagement. Table 6 shows the mean, standard deviation, skewness and kurtosis values of the employee voice and work engagement levels of the Turkish teachers.

Table 6. Mean, standard deviation, skewness and Kurtosis values of employee voice and work engagement

\begin{tabular}{cccccc}
\hline Variables & $\mathrm{N}$ & $\bar{X}$ & $\mathrm{~S}$ & Skewness & Kurtosis \\
\hline Employee Voice & 713 & 3.79 & 0.66 & -.38 & .14 \\
Work Engagement & 713 & 4.10 & 0.50 & -.32 & -.03 \\
\hline
\end{tabular}

In accordance with the research purpose that aforementioned, measured "mean" value for employee voice as $=3.79$, and work engagement as $=4.10$ were presented in Table 6 . Both of them commented as high degree. Also, findings from the analyses revealed that employee voice $(S=.66)$ is more homogenous distribution than work engagement $(\mathrm{S}=.50)$. Finally, "skewness and kurtosis" values of both variables are between +1.5 and -1.5 (Tabachnick \& Fidell, 2013). Therefore, it may be inferred that research dataset is normally distributed.

Next, the study aimed to find out the teachers' perceptions about study variables differed significantly according to gender and tenure. In line with this target, Independent samples t-test results analyzing the variance in employee voice and work engagement according to gender are presented in Table 7.

Table 7. Mean and standard deviation values of the variables and t-test results regarding gender

\begin{tabular}{|c|c|c|c|c|c|c|}
\hline Variables & Gender & $\mathrm{n}$ & $\overline{\bar{X}}$ & SD & $\mathrm{t}$ & $\mathrm{p}$ \\
\hline \multirow{2}{*}{ Employee Voice } & 1.Male & 198 & 3.89 & 0.70 & \multirow{2}{*}{2.498} & \multirow{2}{*}{$0.013 *$} \\
\hline & 2.Female & 515 & 3.75 & 0.64 & & \\
\hline \multirow{2}{*}{ Work Engagement } & 1.Male & 198 & 4.07 & 0.51 & \multirow{2}{*}{-0.751} & \multirow{2}{*}{0.453} \\
\hline & 2.Female & 515 & 4.11 & 0.50 & & \\
\hline
\end{tabular}

$* \mathrm{p}<0.05$.

As seen in Table 7, Employee voice levels of the male teachers $(X=3.89)$ are higher than the female teachers $(t(713)=2,498 ; p<0,05)$. However, work engagement levels of the teachers did not differ significantly by gender. In order to measure the teachers' perceptions about study variables whether differed significantly or not according to their tenure in their job, one way Anova was carried out. ANOVA results are presented in Table 8.

Table 8. ANOVA Results as regards the relation between the variables and the tenure

\begin{tabular}{ccccccc}
\hline Variables & Tenure & $\mathrm{n}$ & $\bar{X}$ & $\mathrm{~S}$ & $\mathrm{~F}$ & $\mathrm{P}$ \\
\hline \multirow{5}{*}{ Employee Voice } & $1.1-5$ years & 131 & 3.79 & 0.56 & & \\
& $2.6-10$ years & 162 & 3.72 & 0.71 & & \\
& $3.11-15$ years & 123 & 3.83 & 0.66 & 1.923 & 0.105 \\
& $4.16-20$ years & 157 & 3.74 & 0.64 & & \\
& 5.21 years and over & 140 & 3.91 & 0.68 & & \\
\hline \multirow{5}{*}{ Work Engagement } & $1.1-5$ years & 131 & 4.14 & 0.44 & & \\
& 2. 6-10 years & 162 & 4.03 & 0.52 & & \\
& 3. 11-15 years & 123 & 4.10 & 0.55 & 1.511 & 0.197 \\
& 4. 16-20 years & 157 & 4.08 & 0.50 & & \\
& 5.21 years and over & 140 & 4.15 & 0.50 & & \\
\hline
\end{tabular}

$\mathrm{p}<0.05$.

As seen in Table 8, Employee voice and work engagement levels of the teachers $(p>0,05)$ did not differ 
significantly by tenure. However, teachers, who have 21 years and over tenure, have higher level of employee voice and work engagement.

In Table 9 the findings from the correlation analysis to detect the relationship between employee voice and work engagement are presented:

Table 9. Correlation between employee voice and work engagement

\begin{tabular}{|c|c|c|}
\hline Variables & & \\
\hline Employee Voice & 1 & $.36^{*}$ \\
\hline Work Engagement & & 1 \\
\hline
\end{tabular}

According to the obtained findings from correlation analysis, the relationship between employee voice and work engagement is significant and positive $(r=.36, \mathrm{p}<.01)$.

Results of the regression analysis regarding the prediction of work engagement by employee voice as a predictor are shown in Table 10:

Table 10. Results of the regression analysis concerning the prediction for work engagement by employee voice as a predictor

\begin{tabular}{ccccccc}
\cline { 2 - 7 } Variables & $\mathrm{B}$ & $\mathrm{SE}$ & $\beta$ & $\mathrm{t}$ & $\mathrm{p}$ \\
\hline Constant & 3.037 & .104 & & 29.304 & $.01^{*}$ \\
Employee Voice & .281 & .027 & .365 & 10.439 & $.01^{*}$ \\
$\mathrm{R}$ & & & & .365 & \\
$\mathrm{R}^{2}$ & & & & .133 & \\
$\mathrm{~F}$ & & & & 108.972 & $.01^{*}$ \\
\hline
\end{tabular}

${ }^{*} \mathrm{p}<.01$; Predictor: Employee Voice.

An evaluation of the findings in Table 10 reveal that employee voice has a positive and significant relation with the work engagement $\left(\mathrm{R}=.365 ; \mathrm{R}^{2}=.133 \mathrm{p}<.01\right)$. In other words, employee voice accounts for $13.3 \%$ of the total variance of work engagement. Thus, it can be inferred from the review of $t$-test results as regards the significance of the regression coefficients results that employee voice is a significant predictor of work engagement.

\section{Discussion}

This research intended to investigate the relationships between employee voice and work engagement in relation to the teachers' opinions. According to the findings that attained from the series of analysis, a positive and significant relationship was found out between employee voice and work engagement. The results of the research are similar to the findings of the other research results available in the literature. Rees et al. (2013) also found out that voice was significantly and positively related to engagement. They stated that there is likely to be a link between employee perceptions of voice and engagement. Moreover, if employees feel that they can share their views, opinions and worries at work without concern, they will possibly show higher levels of engagement. Therefore, employee voice should be encouraged and enabled in the organizations. The findings of the two studies corroborate with each other. Furthermore, some different researches were applied to investigate the relationship between employee voice and work engagement such as Cheng et al. (2013), Holland et al. (2016), Dorothy (2016), Kwon, Farndale, and Park (2016), Ruck et al. (2017), Maymand, Abdollahi, and Elhami (2017), Latif and Arif (2018), Okpu and Kpakol (2018) and Amah (2018). They also discovered that voice behavior is positively associated with work engagement and very essential for engaged employees. Amah (2018) also explained that engaged employees are very inventive and enthusiastic to make recommendations for improving organizational efficiency.

The second important finding of this research is to find out the teachers' perceptions about study variables differed significantly in terms of teachers' gender and tenure. Regarding the relationship between gender and study variables, male teachers display a greater level of employee voice than female teachers. In other words, employee voice levels of the male teacher are higher than that of the female teachers. The results of the present study are consistent with that of Ilgin (2014). Ilgin (2014) found out that women lecturers have less voice behaviours than men lecturers. Furthermore, she identified that some reasons why female lecturers use voice less than males 
because of lack of experience, ostracization and fear of damaging the relationships with the others at work. Morrison and Milliken (2000) also emphasized that gender is one of the main reasons for employees to use voice or not at work.

Another result of the present research was that work engagement levels of the teachers did not differ significantly by gender. Öncel (2007), Basikin (2008), Kavgacı (2014), Sezen (2014), Köse (2015, 2016) and Tan (2015) also demonstrated that there was no significant relationship between work engagement and gender.

Another finding of this research is that teachers' employee voice and work engagement levels did not vary with respect to their tenure and it is recognized that in both factors the highest mean scores for tenure are between 21 years and over. Shortly, the teachers' tenure climbed, it is noted that both employee voice and work engagement levels are getting increased. The results of the present study are consistent with that of Çetin (2013), Bulut and Bayramlık (2015), Köse (2015), Kavgacı (2015), San and Tok (2016).

\section{Conclusion}

The present study investigated the relationship between employee voice and work engagement based on teacher opinions. All the findings and arguments of this study reveal that has a positive and significant relation with the work engagement. Hall and Purcell (2012) stated that having a voice, and being listened to, is one of the most important antecedents of engagement. Truss et al. (2006) also implied that having opportunities for voice behavior at work is one of the main reasons of work engagement. Purcell, Kinnie, Hutchinson, Rayton, and Swart (2003) implied that employees who have voice behaviors directed to their work issues or worries at work openly are positive, problem solver and engaged persons. With the help of these persons, organizations can get a worthy and effective work in the long run. Purcell (2010) also indicated that bad management behaviors in the organizations can cause disengaged employees because of lack of communication and knowledge between the employees and managers.

The present study demonstrated that when the teachers have more voice behaviors at schools, they will be more engaged for their work. Gülbahar (2017) stated that the most innovative and open-minded teachers are those who have a high level of work engagement. The more teachers are engaged in their work, the better their students perform, and the less probably teachers are to leave their jobs (Runhaar, Konermann, \& Sanders, 2013). Furthermore, healthy and engaged teachers are likely to implement and succeed educational objectives better than their coworkers with burnout symptoms (Hakanen, Bakker, \& Schaufeli, 2005) and also effective teaching is dependent on teachers who are motivated: fully engaged in their work, and engaged not just cognitively and emotionally, but also socially (Klassen, Yerdelen, \& Durksen, 2013). In their study, Victor and Patil (2016) ascertained that engaged teachers presented significant creativity, sorted problems out effectively, took active roles in lots of optional duties to develop their schools, reported higher levels of commitment, and implemented their task roles.

All in all, teachers are the key to success of any education system (Shah, Khan, \& Ullah, 2014). That is why both educational policy makers and school managers should take the correct or accepted steps toward improving voice behavior and work engagement at schools. Additionally, it is suggested that more researches with other organizational variables on employee voice and work engagement should be performed to make these issues clearer in educational environments to create better schools and successful students.

\section{References}

Al-Bataineh, A. T., \& Nur-Awaleh, M. A. (2005). International education systems and contemporary education reforms. Lanham, MD: University Press of America.

Amah, O. (2018). Employee engagement in Nigeria: The role of leaders and boundary variables. SA Journal of Industrial Psychology, 44, 1-8. https://doi.org/10.4102/sajip.v44i0.1514

Argyris, C., \& Schön, D. (1978). Organizational learning: A theory of action perspective. Reading, Mass: Addison Wesley. https://doi.org/10.1177/017084068000100310

Bakker, A. B., \& Demerouti, E. (2008). Towards a model of work engagement. Career Development International, 13, 209-223. https://doi.org/10.1108/13620430810870476

Bakker, A. B., \& Schaufeli, W. B. (2008). Positive organizational behavior: Engaged employees in flourishing organizations. Journal of Organizational Behavior, 29, 147-54. https://doi.org/10.1002/job.515

Bakker, A. B., Albrecht, S. L., \& Leiter, M. P. (2011). Work engagement: Further reflections on the state of play. European Journal of Work and Organizational Psychology, 20(1), 74-88. https://doi.org/10.1080/1359432X.2010.546711 
Bies, R. J., \& Shapiro, D. L. (1988). Voice and justification: Their influence on procedural fairness judgements. Academy of Management Journal, 31, 676-685. https://doi.org/10.5465/256465

Botero, I. C., \& Dyne, L. V. (2009). Employee voice behavior: Interactive effects of $\operatorname{lmx}$ and power distance in the United States and Colombia. Management Communication Quarterly, 23(1), 84-104. https://doi.org/10.1177/0893318909335415

Burić, I., \& Macuka, I. (2018). Self-efficacy, emotions and work engagement among teachers: A two wave cross-lagged analysis. Journal of Happiness Studies, 19(7), 1917-1933. https://doi.org/10.1007/s10902-017-9903-9

Büyüköztürk, Ş. (2003). Sosyal bilimler için veri analizi el kitabı. Ankara: Pegem A. https://doi.org/10.14527/9789756802748

Byrne, B. (2010). Structural equation modeling with AMOS: Basic concepts, applications and programming. New York, NY: Taylor and Francis Group.

Cheng, J. W., Lu, K. M., Chang, Y. Y., \& Johnstone, S. (2013). Voice behavior and work engagement: The moderating role of supervisor-attributed motives. Asia Pacific Journal of Human Resources, 51, 81-102. https://doi.org/10.1111/j.1744-7941.2012.00030.x

Corporate Leadership Council. (2004) Driving performance and retention through employee engagement. London: Corporate Executive Board.

Demerouti, E., \& Cropanzano, R. (2010). From thought to action: Employee work engagement and job performance. In A. B. Bakker, \& M. P. Leiter (Eds.), Work engagement: A handbook of essential theory and research (pp. 147-163). New York, NY, US: Psychology Press.

Drucker, P. F., Collins, J., Kotler, P., Kouzes, J., Rodin, J., \& Rangan, V. K. (2008). The five most important questions you will ever ask about your organization (3rd ed.). San Francisco: Jossey-Bass

Farndale, E., Van Ruiten, J., Kelliher, C., \& Hope-Hailey, V. (2011). The influence of perceived employee voice on organizational commitment: An exchange perspective. Human Resource Management, 50(1), 113-129. https://doi.org/10.1002/hrm.20404

Farrell, D., \& Rusbult, C. E. (1992). Exploring the exit, voice, loyalty, and neglect typology: the influence of job satisfaction, quality of alternatives and investment size. Employee Responsibilities and Rights Journal, 5, 201-218. https://doi.org/10.1007/BF01385048

Fornell, C., \& Larcker, D. (1981). Evaluating structural equation models with unobservable variables and measurement error. Journal of Marketing Research, 18, 39-50. https://doi.org/10.2307/3151312

Gülbahar, B. (2017). The relationship between work engagement and organizational trust: A study of elementary school teachers in Turkey. Journal of Education and Training Studies, 5(2), 149-159. https://doi.org/10.11114/jets.v5i2.2052

Gürler, M. (2018). Analyzing the mediating effect of employee voice in the relationship between the teachers' leader-member exchange and work engagement (Unpublished doctoral dissertation). Anadolu University, Eskişehir, Turkey.

Gyurko, J. (2012). Teacher voice (Unpublished doctoral dissertation). Columbia University, Graduate School of Arts and Sciences, New York.

Hakanen, J. J., Bakker, A. B., \& Schaufeli, W. B. (2006). Burnout and Work Engagement among Teachers. Journal of School Psychology, 43, 495-513. https://doi.org/10.1016/j.jsp.2005.11.001

Hall, M., \& Purcell, J. (2012). Consultation at work: Regulation and practice. Oxford: Oxford University Press.

Han, T. S., Chiang, H. H., \& Chang, A. (2010). Employee participation in decision making, psychological ownership and knowledge sharing: Mediating role of organizational commitment in Taiwanese high-tech organizations. The International Journal of Human Resource Management, 21(12), 2218-2233. https://doi.org/10.1080/09585192.2010.509625

Hargreaves, A. (1996). Revisiting voice. Educational Researcher, 25(1), 12-19. https://doi.org/10.3102/0013189X025001012

Hargreaves, A., \& Shirley, D. (2011). The far side of educational reform. Ottawa, Ontario: Canadian Teachers' Federation.

Heneveld, W. (2007). Whose reality counts? local educators as researchers on the quality of primary education. 
International Review of Education, 53(5-6), 639-663. https://doi.org/10.1007/s 11159-007-9059-7

Hirschman, A. O. (1970). Exit, voice, and loyalty, responses to decline in firms, organizations and states. Cambridge, Mass: Harvard University Press. https://doi.org/10.1007/978-3-531-90400-9_48

Holland, P., Cooper, B., \& Sheehan, C. (2017). Employee voice, supervisor support, and engagement: The mediating role of trust. Human Resource Management, 56(6), 915-929. https://doi.org/10.1002/hrm.21809

Holland, P., Pyman, A., Cooper, B., \& Teicher, J. (2011). Employee voice and job satisfaction in Australia: The centrality of direct voice. Human Resource Management, 50(1), 95-111. https://doi.org/10.1002/hrm.20406

Hopkins, D., \& Stern, D. (1996). Quality teachers, quality schools: International perspectives and policy implications. Teaching \& Teacher Education, 12, 501-517. https://doi.org/10.1016/0742-051x(95)00055-o

Hutcheson, G. D., \& Sofroniou, N. (1999). The multivariate social scientist: An introduction to generalized linear models. Thousand Oaks, California: Sage Publications.

Ingersoll, R. M. (2007). Short on power, long on responsibility. Educational Leadership, 65(1), 20-25.

Jöreskog, K. G., \& Sörbom, D. (1993). Lisrel 8: User's guide. Chicago: Scientific Software.

Kalaycı, Ş. (Ed.) (2006). Spss uygulamalı çok değişkenli istatistik teknikleri. Ankara: Asil Yayın Dağıtım.

Karasar, N. (2006). Bilimsel araştırma yöntemi. Ankara: Nobel Yayın Dağııım.

Kaufman, B. E. (2013). Employee voice before Hirschman: Its early history, conceptualization and practice. Andrew Young School of Policy Studies Research Paper Series, 13-04. https://doi.org/10.2139/ssrn.2212906

Klassen, R., Yerdelen, S., \& Durksen, T. (2013). Measuring teacher engagement: The development of the Engaged Teachers Scale (ETS). Frontline Learning Research, 1(2), 33-52. https://doi.org/10.14786/flr.v1i2.44

Kline, R. B. (2011). Principles and practice of structural equation modeling. New York: The Guilford Press.

Kwon, B., Farndale, E., \& Park, J. G. (2016). Employee voice and work engagement: Macro, meso and micro-level drivers of convergence? Human Resource Management Review, 26(4), 327-337. https://doi.org/10.1016/j.hrmr.2016.04.005

Latif, N. Z. A., \& Arif, L. S. M. (2018). Employee engagement and employee voice. International Journal of Academic Research in Progressive Education and Development, 7(3), 507-515. http://dx.doi.org/10.6007/IJARPED/v7-i3/4569

Liang, G., Yehuda, B., \& Russo, M. (2017). Work resources and civic engagement: Benefits to employee physical and mental health. Journal of Vocational Behavior, 100, 56-66. https://doi.org/10.1016/j.jvb.2017.02.007

Luthans, F. (2002). Positive organizational behavior: Developing and managing psychological strengths. Academy of Management Executive, 16(1), 57-72. https://doi.org/10.5465/ame.2002.6640181

Markow, D., \& Pieters, A. (2010). The metlife survey of the American teacher: collaborating for student success. New York, NY: Metlife.

Maymand, M. M., Abdollahi, M., \& Elhami, S. (2017). The effect of employee voice on work engagement through trust in management. Journal of Administrative Management, Education and Training, 13(Special Issue 1), 476-483.

Morrison, E. F., \& Milliken, F. J. (2000). Organizational silence: A barrier to change and development in a pluralistic academy of management. The Academy of Management Review, 25(4), 706-725. https://doi.org/10.2307/259200

Morrison, E. W. (2011). Employee voice behavior: Integration and directions for future research. The Academy of Management Annals, 5(1), 373-412. https://doi.org/10.5465/19416520.2011.574506

Morrison, E. W. (2014). Employee voice and silence. Annual Review of Organizational Psychology and Organizational Behavior, 1, 173-197. https://doi.org/10.1146/annurev-orgpsych-031413-091328

Mushava, P. D. (2016). An investigation on the adoption of employee voice and its impact on employee engagement: A case for Zimbabwe revenue authority (Unpublished master's thesis). Lupane State University, Faculty of Commerce, Department of Business Management, Zimbabwe.

Nemeth, C. J. (1985). Dissent, group process, and creativity. Advances in Group Processes, 2, 57-75. 
Nunnally, J. C., \& Bernstein, I. H. (1994). Psychometric theory (3rd ed.). New York, NY: McGraw-Hill.

Okpu, T., \& Kpakol, A. G. (2018). Enhancing job engagement through employee voice in Nigerian banking industry. IOSR Journal of Business and Management, 20(1), 24-34. http://doi.org/10.9790/487X-2001072434

Peterson, R. (2000). A meta-analysis of variance accounted for and factor loadings in exploratory factor analysis. Marketing Letters, 11, 261-275. https://doi.org/10.1023/A:1008191211004

Premeaux, S. F., \& Bedeian, A. G. (2003). Breaking the silence: the moderating effects of self-monitoring in predicting speaking up in the workplace. Journal of Management Studies, 40, 1537-1562. https://doi.org/10.1111/1467-6486.00390

Purcell, J. (2010). Building employee engagement. ACAS Policy Discussion Paper, London: ACAS.

Purcell, J. (2014). Time to focus on employee voice as a prime antecedent of engagement: Rediscovering the black box. The Future of Engagement Thought Piece Collection, 1, 21-26.

Purcell, J., Kinnie, N., Hutchinson, S., Rayton, B., \& Swart, N. (2003). Understanding the people and performance link: Unlocking the black box (Research Report). London: CIPD. https://doi.org/10.4324/9780203885604

Rees, C., Alfes, K., \& Gatenby, M. (2013). Employee voice and engagement: Connections and consequences. The International Journal of Human Resource Management, 24(14), 2780-2798. https://doi.org/10.1080/09585192.2013.763843

Reissner, S., \& Pagan, V. (2013). Generating employee engagement in a public-private partnership: Management communication activities and employee experiences. The International Journal of Human Resource Management, 24, 2741-2759. https://doi.org/10.1080/09585192.2013.765497

Ruck, K., Welch, M., \& Menara, B. (2017). Employee voice: An antecedent to organizational engagement? Public Relations Review, 43(5), 904-914. http://doi.org/10.1016/j.pubrev.2017.04.008

Runhaar, P., Konermann, J., \& Sanders, K. (2013). Teachers' organizational citizenship behaviour: Considering the roles of their work engagement, autonomy and leader-member exchange. Teaching and teacher education, 30(1), 99-108. https://doi.org/10.1016/j.tate.2012.10.008

Rusbult, C. E., Zembrodt, I. M., \& Gunn, L. K. (1982). Exit, voice, loyalty, and neglect: Responses to dissatisfaction in romantic involvements. Journal of Personality and Social Psychology, 43(6), 1230. https://doi.org/10.1037/0022-3514.43.6.1230

Saks, A. M., \& Gruman, J. A. (2011). Getting newcomers engaged: The role of socialization tactics. Journal of Managerial Psychology, 26(5), 383-402. https://doi.org/10.1108/02683941111139001

Schaufeli, W. B., \& Bakker. A. B. (2004). Test manual for the Utrecht work engagement scale (Unpublished Manuscript). Utrecht University, The Netherlands.

Schaufeli, W. B., Bakker, A. B., \& Salanova, M. (2006). The measurement of work engagement with a short questionnaire: A cross-national study. Educational and Psychological Measurement, 66, 701-716. https://doi.org/10.1177/0013164405282471

Schaufeli, W. B., Salanova, M., Gonzàlez-Romà, V., \& Bakker, A. B. (2002). The measurement of burnout and engagement: A two sample confirmative analytic approach. Journal of Happiness Studies, 3(1), 71-92. https://doi.org/10.1023/A:1015630930326

Senge, P. M. (1990). The fifth discipline: the art and practice of the learning organization. New York: Doubleday Business.

Shah, S. F., Khan, D., \& Ullah, I. (2014). Problems faced by female teachers at primary level in Khyber Pakhtunkhwa Pakistan. International Journal of Elementary Education, 3(2), 34-40. http://doi.org/10.11648/j.ijeedu.20140302.13

Smith, A. (2000). The wealth of nations. Adam Smith; Introduction by Robert Reich; Edited, with notes, marginal summary, and enlarged index by Edwin Cannan. New York: Modern Library.

Sonnentag, S. (2003). Recovery, work engagement, and proactive behavior: A new look at the interface between nonwork and work. Journal of Applied Psychology, 88, 518-528. https://doi.org/10.1037/0021-9010.88.3.518

Spencer, D. G. (1986). Employee voice and employee retention. Academy of Management Journal, 29, 488-502. 
https://doi.org/10.2307/256220

Tabachnick, B. G., \& Fidell, L. S. (2007). Using Multivariate Statistics (5th ed.). New York: Allyn and Bacon.

Tabachnick, B. G., \& Fidell, L. S. (2013). Using Multivariate Statistics (6th ed.). Boston: Ma: Pearson.

Truss, C., Soane, E., Edwards, C., Wisdom, K., Croll, A., \& Burnett, J. (2006). Working Life: Employee Attitudes and Engagement (Research Report). London: CIPD.

Van Dyne, L., \& Lepine, J. A. (1998). Helping and voice extra-role behaviors: Evidence of construct and predictive validity. Academy of Management Journal, 4l(1), 108-119. http://doi.org/10.2307/256902

Victor, S. R., \& Patil, U. (2016). Work engagement and teacher autonomy among secondary school teacher. Hamburg: Anchor Academic Publishing.

Wilkinson, A., Gollan, P. J., Kalfa, S., \& Xu, Y. (2018). Voices unheard: Employee voice in the new century. The International Journal of Human Resource Management, 29(5), 711-724. https://doi.org/10.1080/09585192.2018.1427347

Wood, S., \& De Menezes, L. M. (2011). High involvement management, high performance work systems and well-being. The International Journal of Human Resource Management, 22, 1586-1610. https://doi.org/10.1080/09585192.2011.561967

\section{Copyrights}

Copyright for this article is retained by the author(s), with first publication rights granted to the journal.

This is an open-access article distributed under the terms and conditions of the Creative Commons Attribution license (http://creativecommons.org/licenses/by/4.0/). 